\title{
The effects of inflammatory cytokines on the expression of ghrelin
}

\author{
Hiroshi Iwakura, Mika Bando, Yoko Ueda and Takashi Akamizu
}

The First Department of Medicine, Wakayama Medical University, Wakayama 841-8509, Japan

\begin{abstract}
In the current study, we examined the effects of LPS and inflammatory cytokines including IL-1 $\beta$, TNF- $\alpha$, and IL-6 on the expression of ghrelin in MGN3-1 cells. We found that IL-1 $\beta$, and TNF- $\alpha$ with lesser extent, significantly suppressed ghrelin mRNA expression in the cells. MGN3-1 cells expressed IL-1 $\beta$ receptor and IL-1 $\beta$ significantly stimulated NF- $\mathrm{kB}, \mathrm{p} 38$, JNK, and ERK pathways. Knockdown of IKK2 by siRNA significantly attenuated the suppression of ghrelin mRNA by IL- $1 \beta$. These results indicate that IL- $1 \beta$ directly suppressed ghrelin mRNA via NF- $\kappa$ B pathway at least partially, which may have a role in the regulation of appetite during inflammation.
\end{abstract}

Key words: Ghrelin, IL-1, TNF- $\alpha$, NF- $\kappa \mathrm{B}$

IT IS WELL KNOWN that infection induces anorexia in the host, which is considered to be mediated by microbial products and cytokines [1]. Ghrelin is an orexigenic hormone, mainly produced by the stomach [2], playing major roles in the regulation of food intake [3]. It has been reported that systemic administration of LPS suppresses plasma ghrelin levels in rats $[4,5]$. It remains unclear the molecular mechanisms involved in the LPS-induced ghrelin regulation. Previously, we established a ghrelin-producing cell line MGN3-1 [6], originated from a gastric ghrelinoma developed in ghrelin-promoter SV40 Tag transgenic mice [7], in order to explore the mechanism of ghrelin production and secretion in molecular basis $[1,8,9]$. In the current study, we examined the effects of LPS and inflammatory cytokines including IL- $1 \beta$, TNF- $\alpha$, and IL- 6 on the expression of ghrelin in MGN3-1 cells [10].

\section{Materials and Methods}

Detailed materials and methods were described previously [10].

Correspondence to: Hiroshi Iwakura, The First Department of Medicine, Wakayama Medical University, 811-1 Kimiidera, Wakayama 641-8509, Japan.

E-mail: hiwaku@wakayama-med.ac.jp

(C) The Japan Endocrine Society

\section{Results and Discussion}

LPS is recognized by Toll-like receptor 4 on the various kinds of the cells, activating intracellular signaling pathways such as NF-kB, p38, JNK, and ERK, triggering the release of cytokines including IL-1 $\beta$, TNF- $\alpha$ and IL-6 [11]. We first examined the effects of these cytokines and LPS on the ghrelin mRNA levels in MGN3-1 cells to reveal if the reported suppressive effects of LPS on ghrelin mRNA levels in animal models were direct or indirect. We found that IL-1 $\beta$, and TNF- $\alpha$ with lesser extent, significantly suppressed ghrelin mRNA expression levels in the cells, while neither IL-6 nor LPS showed any effect on ghrelin mRNA levels, suggesting that the suppressive effects of LPS on the ghrelin mRNA levels were indirect, primarily mediated by IL- $1 \beta$. Reflecting the suppression of ghrelin production, ghrelin secretion from MGN3-1 cells was also significantly suppressed after IL- $1 \beta$ treatment.

MGN3-1 cells and at least part of the ghrelin-producing cells in the mouse stomach expressed IL- $1 \beta$ receptor. IL- $1 \beta$ significantly stimulated NF- $\mathrm{B}$, $\mathrm{p} 38$, JNK, and ERK pathways in MGN3-1 cells. Knockdown of IKK2, one of the key molecules in NF- $\mathrm{kB}$ pathway, with siRNA significantly attenuated the suppression of ghrelin mRNA by IL-1 $\beta$, while inhibitors of JNK 
p38 MAPK and ERK pathways had no effects on the suppression of ghrelin mRNA levels by IL-1 $\beta$. These results indicate that IL-1 $\beta$ directly suppressed ghrelin mRNA via NF- $\kappa B$ pathway at least partially.

Asakawa et al. reported that administration of IL-1 $\beta$ to mice suppressed ghrelin mRNA in the stomach [12]. Our results were consistent with their findings. IL- $1 \beta$ has roles not only in the inflammatory processes but also in the regulation of food intake, by suppressing it
$[13,14]$. Considering the potent orexigenic activity of ghrelin, it seems reasonable that ghrelin production is suppressed by IL- $1 \beta$.

In conclusion, IL-1 $\beta$, but not LPS, directly suppressed ghrelin mRNA expression in the ghrelin-producing cells, suggesting the role of ghrelin in the IL-1 $\beta$ mediated anorexia during inflammation. The details of the current study have been published previously [10].

\section{References}

1. Koyama H, Iwakura H, Dote K, Bando M, Hosoda H, Ariyasu H, Kusakabe T, Son C, Hosoda K, Akamizu T, Kangawa K, Nakao K (2016) Comprehensive Profiling of GPCR Expression in Ghrelin-Producing Cells. Endocrinology157: 692-704.

2. Kojima M, Hosoda H, Date Y, Nakazato M, Matsuo H, Kangawa K (1999) Ghrelin is a growth-hormonereleasing acylated peptide from stomach. Nature 402: 656-660.

3. Nakazato M, Murakami N, Date Y, Kojima M, Matsuo H, Kangawa K, Matsukura S (2001) A role for ghrelin in the central regulation of feeding. Nature 409: 194-198.

4. Hataya Y, Akamizu T, Hosoda H, Kanamoto N, Moriyama K, Kangawa K, Takaya K, Nakao K (2003) Alterations of plasma ghrelin levels in rats with lipopolysaccharide-induced wasting syndrome and effects of ghrelin treatment on the syndrome. Endocrinology 144: 5365-5371.

5. Iwakura H, Kangawa K, Nakao K (2015) The regulation of circulating ghrelin - with recent updates from cellbased assays [Review]. Endocrine journal 62: 107-122.

6. Iwakura H, Li Y, Ariyasu H, Hosoda H, Kanamoto N, Bando M, Yamada G, Hosoda K, Nakao K, Kangawa K, Akamizu T (2010) Establishment of a novel ghrelinproducing cell line. Endocrinology 151: 2940-2945.

7. Iwakura H, Ariyasu H, Li Y, Kanamoto N, Bando M, Yamada G, Hosoda H, Hosoda K, Shimatsu A, Nakao K, Kangawa K, Akamizu T (2009) A mouse model of ghrelinoma exhibited activated growth hormone-insulin-like growth factor I axis and glucose intolerance. Am J Physiol Endocrinol Metab 297: E802-811.
8. Iwakura H, Ariyasu H, Hosoda H, Yamada G, Hosoda K, Nakao K, Kangawa K, Akamizu T (2011) Oxytocin and dopamine stimulate ghrelin secretion by the ghrelinproducing cell line, MGN3-1 in vitro. Endocrinology 152: 2619-2625.

9. Bando M, Iwakura H, Koyama H, Hosoda H, Shigematsu Y, Ariyasu H, Akamizu T, Kangawa K, Nakao K (2016) High incorporation of long-chain fatty acids contributes to the efficient production of acylated ghrelin in ghrelinproducing cells. FEBS Lett 590: 992-1001.

10. Bando M, Iwakura H, Ueda $\mathrm{Y}$, Ariyasu H, Inaba H, Furukawa Y, Furuta H, Nishi M, Akamizu T (2017) IL-1beta directly suppress ghrelin mRNA expression in ghrelin-producing cells. Mol Cell Endocrinol 447:45-51.

11. Aderem A, Ulevitch RJ (2000) Toll-like receptors in the induction of the innate immune response. Nature 406: 782-787.

12. Asakawa A, Inui A, Kaga $T$, Yuzuriha $H$, Nagata $T$, Ueno N, Makino S, Fujimiya M, Niijima A, Fujino MA, Kasuga M (2001) Ghrelin is an appetite-stimulatory signal from stomach with structural resemblance to motilin. Gastroenterology 120: 337-345.

13. Garcia MC, Wernstedt I, Berndtsson A, Enge M, Bell M, Hultgren O, Horn M, Ahren B, Enerback S, Ohlsson C, Wallenius V, Jansson JO (2006) Mature-onset obesity in interleukin-1 receptor I knockout mice. Diabetes 55: 1205-1213.

14. Luheshi GN, Gardner JD, Rushforth DA, Loudon AS, Rothwell NJ (1999) Leptin actions on food intake and body temperature are mediated by IL-1. Proc Natl Acad Sci U S A 96: 7047-7052. 